\title{
Law Enforcement Implementation Against Domestic Violence
}

\author{
I Dewa Made Sarwa Mandala*) and Sri Endah Wahyuningsih ${ }^{* *}$ \\ ${ }^{*}$ S Student of Masters (S2) of Law Faculty of Law Unissula and Attorney of Sampang \\ Madura Regency, email: putridewani3@gmail.com \\ **) Faculty of Law Universitas Islam Sultan Agung
}

\begin{abstract}
In essence, domestic violence is not only contrary to Pancasila as a source of law in Indonesia, it is also against the 1945 Constitution of the Indonesian State. The formulation of the problem in this research is: the causes of the Crime of Domestic Violence (DV) which hinders the Criminal Law Policy in tackling the Crime of Domestic Violence (DV) and the Implementation of Law Enforcement of the Crime of Domestic Violence (DV). The method used is a sociological juridical legal approach and the specifications in this study include descriptive analytical. The sources and types of data in this study are primary data. And secondary data obtained from literature studies related to theory of Law Enforcement and Legal System. Based on the results of that research A patriarchal culture that places men as superior beings and women as interior creatures; Incorrect understanding of religious teachings so that men can dominate women; The imitation of a boy who lives with a beating father will usually imitate his father's behavior. Different understandings between law enforcers on Domestic Violence (DV); The length of time between the incident and the post mortem, so that the post mortem results are less supportive of the legal process; Cases reported by victims are often not followed up, because victims are doubtful or do not understand that what is being reported is a criminal act. By means of preemptive efforts, carried out by the police to prevent criminal acts. Preventive measures are also carried out as follow-up efforts to pre-emptive efforts that are still at the level of prevention before the occurrence of crimes. As well as repressive measures are carried out when there has been a crime / crime in which the action is law enforcement by imposing a sentence.

Keywords: Law Enforcement, Crime, Domestic Violence
\end{abstract}

\section{Introduction}

As it is known, the Criminal Code (WvS) in effect in Indonesia so far has not formulated general criminal guidelines governing judge forgiveness. The formulation of the principle of rechterlijk in the criminal guidelines is important because it is appropriate for the flexibility / elasticity and modification of punishment which comes from the values of religious wisdom. ${ }^{1}$

Domestic violence has become a separate discourse in everyday life. In general, in the kinship structure in Indonesia, men are placed in a dominant position, namely as the head of the family. Thus, it is not unusual for other family members to become very dependent on men. Such a superior male position often causes him to become very powerful in the midst of the family circle. Even when men commit various violations of violence against other family members where women and children are the main victims, no one can stop it.

Criminal law is public law, so that the main objective of holding criminal law is to protect the interests of society as a collectivity from actions that threaten or

${ }^{1}$ Sri Endah Wahyuningsih, 2018, Model Pengembangan Asas Hukum Pidana Dalam KUHP Berbasis Nilai-nilai Ketuhanan Yang Maha Esa, Fastindo, Semarang, p. 128 
even harm them, whether they come from individuals or groups of people (an organization) ${ }^{2}$. An act can be said to be a criminal act if the act has been regulated in legislation. This is in line with the legality principle, which contains 3 (three) basic principles:

a. There is no crime without a law;

b. There is no crime without a criminal act;

c. There is no criminal act without the first existing criminal law. ${ }^{3}$

Husband's violence against his wife can be caused by several factors, both internal and external. The factors that cause husband violence against wife are as follows:

a. The fact that men and women are not positioned equally in society.

b. Society still raises boys with education that is based on physical strength, that is, to foster the belief that they must be strong and courageous and intolerant.

c. Culture conditions women or wives depending on men or on their husbands, especially economically.

d. Perceptions of violence that occur in the household are considered to be closed because it is included in the privacy area of husband and wife and not as a social issue.

e. Incorrect understanding of religious teachings regarding respect for the husband's position, about the rules for educating wives, and about the teachings of wives' obedience to their husbands.

f. The husband's personality and psychological condition is unstable and incorrect ${ }^{4}$

Violence against women is a violation of human rights. Violence in the view of science is the more common and widespread the frequency of crimes followed by violence in society, the thicker the public's belief in the importance and seriousness of this kind of crime. What is meant by violent crime is if violence is used in such a way as to cause damage, both physical and psychological, is violence that is against the law. ${ }^{5}$.

For example, a case of domestic violence committed by a husband against his wife that occurred recently in the city of Semarang. However, the case was not exposed because the case was not forwarded or reported by the victim's family to the Police. In that incident, the husband beat his wife and hit her head against the wall which caused her to feel pain and cry hysterically, which in the end a few days later her wife died.

\section{Research Methods}

The research method used in this research is sociological juridical law research, that is, in searching for data, it is carried out by field research related to

\footnotetext{
${ }^{2}$ Ismu Gunadi \& Jonaedi Efendi, 2014, Cepat dan mudah memahami hukum pidana, Kencana Prenadamedia Grup, Jakarta, p. 11

${ }^{3}$ Aluysius Sutikna, Sri Kusriyah, Implementasi Undang-Undang Nomor 30 Tahun 2014 Tentang Administrasi Pemerintahan Terhadap Proses Penyidikan Tindak Pidana Korupsi Di Polres Rembang, Jurnal Hukum Khaira Ummah Vol. 13. No. 1 March 2018

${ }^{4}$ Romli Atma Sasmita, 1992, Teori dan Kapita Selekta Kriminologi. Rapika Aditama, Bandung, p.53

${ }^{5}$ Ibid, p. 55
} 
domestic violence (DV). This research uses juridical sociological legal research because it examines the provisions regarding Domestic Violence (DV). Besides, this research is also supported by field research. ${ }^{6}$ The specifications in this study include descriptive analytical. The sources and types of data in this study are primary data. And secondary data obtained from literature studies related to the theory of Law Enforcement and Legal Systems.

\section{Result And Discussion}

\subsection{Causes of Crime of Domestic Violence (DV)}

Ratna Batara Munti explained that violence against women in the household can occur in various forms as summarized below, namely: ${ }^{7}$

a. Direct physical violence in the form of beatings, scratching to destroying the vagina (sexual violence) and indirect physical violence, usually in the form of hitting tables, slamming doors, breaking plates, glasses, flower holders, etc., and being rude.

b. Psychological violence, in the form of harsh, obscene speech, and the connotation of belittling and insulting, silence, terrorizing either directly or using certain media, having an affair, and leaving without clarity for a long time and without responsibility.

c. Economic violence, in the form of not giving a living during a marriage or limiting income arbitrarily, allowing or even forcing a wife to work hard, as well as not providing income after a divorce occurs even though the court ruled.

$\mathrm{d}$. The combination of various violence as mentioned above, whether physical, psychological, or economic.

By referring to Article 5 of Act No. 23 of 2004 concerning the Elimination of

Domestic Violence, domestic violence can take the form of: 8

a. Physical violence, namely actions that cause pain, fall ill, or are seriously injured;

b. Psychic Violence, namely actions that cause fear, loss of self-confidence, loss of ability to act, feeling helpless, and / or severe psychological suffering to a person;

c. Sexual violence which includes: forcing sexual relations against people who live within the scope of the household, forcing sexual relations between one person within the scope of his household with another person for commercial purposes and / or certain purposes;

d. Household neglect, namely every person who neglects a person within the scope of his household, even though according to the law that applies to him or because of an agreement or agreement he is obliged to provide life, care or maintenance to that person. The definition of neglect includes any person who

${ }^{6}$ Abdul Kadir Muhamad, 2004, Hukum dan Penelitian Hukum, Citra Aditya Bakti, Bandung, p. 101

${ }^{7} \mathrm{R}$ Ratna Batara Munti, 2000, Advokasi Legislatif Untuk Perempuan: Sosialisasi Masalah dan Draft Rancangan Undang-Undang Kekerasan Dalam Rumah Tangga, LBH APIK, Jakarta, p. 36.

8Muhadar, Edi Abdullah, Husni Thamrin, 2009, Perlindungan Saksi dan Korban dalam Sistem Peradilan Pidana, Putra Media Nusantara, Surabaya, p. 80. 
results in economic dependence by limiting and / or prohibiting proper work in or outside the home so that the victim is under the control of that person.

According to Mr. Fahmi Afriyanto, that domestic violence that tends to occur is physical violence and sexual violence because it is easier to prove it is in the form of post mortem. Apart from that, what often receives complaints is that there is neglect in the household. Meanwhile, complaints about psychological violence rarely occur because proof of psychological violence is quite difficult, cannot be seen in the post mortem and can only be felt by the victim. ${ }^{9}$

The factors that cause violence against women put forward by Aina Rumiati: 10

a. A patriarchal culture that places men as superior beings and women as interior creatures.

b. Wrong understanding of religious teachings so that men can dominate women.

c. The imitation of a boy who lives with a beating father will usually imitate his father's behavior.

According to the authors, it is studied with law enforcement theory regarding the causes of Crime of Domestic Violence in the Legal Area of the Semarang Police, that the identification of the causes of domestic violence can also basically be used as a basis for determining policy steps or in designing program management forms for both preventive and advocacy efforts, coordination and monitoring and evaluation of their effectiveness and repressive measures. Likewise, policies that will make solutions to the root problems become very important to be placed as a priority.

\subsection{Factors Obstructing Criminal Law Policies in Handling Criminal Actions of Domestic Violence (DV)}

There are several factors that hinder the Criminal Law Policy in tackling the Crime of Domestic Violence (DV) in the city of Semarang. According to the results of an interview with Ms. Umarsini, the obstacles in the handling of victims of the Crime of Domestic Violence (DV) in the city of Semarang, include: 11

a. Cases of Domestic Violence (DV) that are reported by victims are often not followed up, because the victims are hesitant or do not understand that what is being reported is a criminal act. Likewise, cases that have been processed by the Police are often withdrawn for various reasons, for example because the victim feels that he has forgiven the perpetrator, the economic dependence on the perpetrator, as well as that Domestic Violence (DV) is still considered a family disgrace;

b. Different understandings between law enforcers on Domestic Violence (DV);

b. The length of time between the incident and post mortem, so that the post mortem results are less supportive of the legal process;

\footnotetext{
9 Interview with AKBP Fahmi Afrianto, SH, SIK, MH, M.Si, on April 8, 2020.

${ }^{10}$ Aina Rumiati Aziz, 2002, Perempuan Korban di Ranah Domestik, www.indoesia.com, p.2

11 Interview with the Head of PPA Mrs. Umarsini on April 9, 2020.
} 
c. Problems with budgeting for outreach to areas that are difficult to reach, resulting in inadequate frequency, and funding for shelters for both buildings and operations;

d. In the health sector, the provincial health offices find it difficult / there is no power to command the district / city health offices, as a result of the implementation of regional autonomy, as a result the formation of PPT in hospitals and health centers is only limited to guidance and advice;

e. Handling cases of Domestic Violence (DV) is not considered a priority, so the formation of PPT is still stuck;

f. The substance of the punishment as referred to in the provisions of Article 44Article 49 of the Republic of Indonesia Law on the Elimination of Domestic Violence hinders the elimination of Domestic Violence (DV), because defendants with an established economy tend to choose fines rather than imprisonment. In the author's opinion that this will actually be largely determined by the role of the judge who will determine the severity of the criminal verdict against the perpetrator in the case of Domestic Violence (DV). For this reason, training is needed to increase gender sensitization among judges including sensitization. In favor of victim justice, the victim is more often women and / or children.

In field practice, the findings of the study show that apart from the Police institution that handles and resolves cases of Domestic Violence (DV), it is very pro-active in taking part in solving problems of Domestic Violence (DV). In addition, Local Government Agencies (Semarang City Women's Empowerment Section) also participate in socializing issues of Domestic Violence (DV) and their handling. ${ }^{12}$

According to the author, it is studied with the theory of the legal system regarding the factors that hinder the implementation of the Criminal Law Policy against Domestic Violence in the Legal Area of the Semarang Police that the impact of violence against women and children in this household, not all victims are wives with easy and willing to provide information about events / treatments experienced in the household. Nevertheless, from some information the victim is the wife who is the sample of the victim, it can be described that the act of physical violence perpetrated by the husband as the perpetrator is not an act of violence that has a mild impact, but has fatalistic consequences and has a profound psychological impact on the victim. In this regard, that as long as they live in the institution of marriage, they always experience suffering both physically and psychologically as a result of the violence perpetrated by the perpetrator (husband). As a result of the violence (maltreatment), apart from bruising, bleeding wounds from sharp points, bruising and swelling of the eyes and head, they also experienced fainting or unconsciousness, so that the impact of the violence caused the victim to become visually impaired and frequent dizziness and experiencing liver symptoms. Likewise, another victim, namely he experienced physical violence that was very fatalistic, which resulted in prolonged physical weakness. They always experience suffering both physically and psychologically as a result of violent treatment by the perpetrator (husband). As a result of the violence (maltreatment), apart from bruising, bleeding wounds from sharp points,

12 Ibid. 
bruising and swelling of the eyes and head, they also experienced fainting or unconsciousness, so that the impact of the violence caused the victim to become visually impaired and frequent dizziness and experiencing liver symptoms. Likewise, another victim, namely he experienced physical violence that was very fatalistic, which resulted in prolonged physical weakness. They always experience suffering both physically and psychologically as a result of violent treatment by the perpetrator (husband). As a result of the violence (maltreatment), apart from bruising, bleeding wounds from sharp points, bruising and swelling of the eyes and head, they also experienced fainting or unconsciousness, so that the impact of the violence caused the victim to become visually impaired and frequent dizziness and experiencing liver symptoms. Likewise, another victim, namely he experienced physical violence that was very fatalistic, which resulted in prolonged physical weakness. They have also experienced fainting or unconsciousness, so that the impact of the violence has caused the victim to become visually impaired and often feel dizzy and experience liver symptoms. Likewise, another victim, namely he experienced physical violence that was very fatalistic, which resulted in prolonged physical weakness. They have also experienced fainting or unconsciousness, so that the impact of the violence has caused the victim to become visually impaired and often feel dizzy and experience liver symptoms. Likewise, another victim, namely he experienced physical violence that was very fatalistic, which resulted in prolonged physical weakness.

\subsection{Implementation of Law Enforcement on Crime of Domestic Violence (DV)}

According to the father's explanation Fahmi Afrianto, that domestic violence is the most common violent crime reported to the police and usually involves both male and female offenders as victims. Victims of domestic violence have requested help through the criminal justice system. Women's rights activists have advocated that perpetrators should be arrested, prosecuted and punished in the same way as other perpetrators of violence. ${ }^{13}$

In carrying out their duties in handling criminal cases, investigators and public prosecutors have established functional and institutional relationships between investigators and public prosecutors. The functional and institutional relationship between the criminal justice component of the Police and the Prosecutor's Office has been established since the notification of the commencement of the investigation. ${ }^{14}$

The existence of the Law on the Elimination of Domestic Violence is important, because this Law includes a mechanism based on the needs and interests of the victim, which are as follows:

a. The obligation of society and the state to protect victims

b. An order for protection of the victim and an order for temporary restriction of movement for the perpetrator

c. Legal assistance for victims

\footnotetext{
${ }^{13}$ Interview with AKBP Fahmi Afrianto, Op.Cit.

${ }^{14}$ Aris Sophian, Umar Ma'ruf, Fulfillment of Restitution Rights In The Level Of Investigation In The Big Semarang City Resort Police In Beating Criminal Case, Jurnal Daulat Hukum Volume 3 Issue 2, June 2020 ISSN: 2614-560X
} 
d. Witness protection

e. Alternative procedures for filing claims

f. Evidence procedures that do not make it difficult for the victim, the victim's testimony can be used and strengthened by expert testimony, so the case can continue to be submitted to prosecution

g. The evidence tool also applies a psychiatric post mortem

$\mathrm{h}$. Integrated handling of legal agencies, medical agencies or other government agencies and social community institutions. ${ }^{15}$

According to the father's explanation Fahmi Afrianto, that in the application of Law Enforcement against perpetrators of criminal acts of Domestic Violence (DV) that occurs by carrying out investigations against the perpetrators. ${ }^{16}$

According to the father's explanation Fahmi Afrianto, the prevention of domestic violence in Semarang City is carried out in 3 (three) stages, namely ${ }^{17}$ :

a. Pre-emptive Efforts

b. Preventive Efforts

c. Repressive Efforts

According to the authors, the theory of legal protection for victims of criminal acts of domestic violence is reviewed, so for the aforementioned implementation, the central government and local governments can cooperate with the community or other social institutions (Article 13 and Article 14 of the DV Law). The provisions regarding this matter of course require the support of facilities and infrastructure that can support it, so that victims can be handled proportionally, including the availability of human resources who have skills and sensitivity to victims, for example, a high sense of sympathy and empathy for victims.

Broadly speaking, the researcher describes the results of research on efforts to implement legal policies in tackling the criminal act of Domestic Violence (DV) in the city of Semarang, is in accordance with the mandate of the Law on the Elimination of Domestic Violence, and has carried out according to the procedures and legislation.

\section{Closing}

A patriarchal culture that places men as superior beings and women as interior creatures; Incorrect understanding of religious teachings so that men can dominate women; The imitation of a boy who lives with a beating father will usually imitate his father's behavior. Factors that hinder the Criminal Law Policy in Handling Crime of Domestic Violence (DV): Different understandings between law enforcers on Domestic Violence (DV); The length of time between the incident and the post mortem, so that the post mortem results are less supportive of the legal process; Cases reported by victims are often not followed up, because victims are doubtful or do not understand that what is being reported is a criminal act. The implementation of law enforcement against the Crime of Domestic Violence (DV),

\footnotetext{
${ }^{15}$ Act No. 23 of 2004 concerning Elimination of Domestic Violence

${ }^{16}$ Interview with AKBP Fahmi Afrianto, Op.Cit.

17 Ibid.
} 
namely by means of preemptive efforts, carried out by the police to prevent criminal acts. Preventive measures are also carried out as follow-up efforts to preemptive efforts that are still at the level of prevention before the occurrence of crimes. As well as repressive measures are carried out when there has been a crime / crime in which the action is law enforcement by imposing a sentence. For law enforcers to always improve their professionalism as an apparatus for protecting the community so that they always provide legal assistance and witness protection, regardless of who the victim, witness, and perpetrator are. For the community to always be vigilant, brave, responsive and quick to report incidents of domestic violence (DV) to the authorities.

\section{References}

\section{Journals:}

[1] Aris Sophian, Umar Ma'ruf, Fulfillment of Restitution Rights In The Level of Investigation In The Big Semarang City Resort Police In Beating Criminal Case, Jurnal Daulat Hukum Volume 3 Issue 2, June 2020 ISSN: 2614-560X

[2] Aluysius Sutikna, Sri Kusriyah, Implementasi Undang-Undang Nomor 30 Tahun 2014 Tentang Administrasi Pemerintahan Terhadap Proses Penyidikan Tindak Pidana Korupsi Di Polres Rembang, Jurnal Hukum Khaira Ummah Vol. 13. No. 1 March 2018

\section{Books:}

[1] Abdul Kadir Muhamad, 2004, Hukum dan Penelitian Hukum, Citra Aditya Bakti, Bandung

[2] Ismu Gunadi \& Jonaedi Efendi, 2014, Cepat dan mudah memahami hukum pidana, Kencana Prenadamedia Grup, Jakarta

[3] Muhadar, Edi Abdullah, Husni Thamrin, 2009, Perlindungan Saksi dan Korban dalam Sistem Peradilan Pidana, Putra Media Nusantara, Surabaya

[4] R Ratna Batara Munti, 2000, Advokasi Legislatif Untuk Perempuan: Sosialisasi Masalah dan Draft Rancangan Undang-Undang Kekerasan Dalam Rumah Tangga, LBH APIK, Jakarta

[5] Romli Atma Sasmita, 1992, Teori dan Kapita Selekta Kriminologi. Rapika Aditama, Bandung

[6] Sri Endah Wahyuningsih, 2018, Model Pengembangan Asas Hukum Pidana Dalam KUHP Berbasis Nilai-nilai Ketuhanan Yang Maha Esa, Fastindo, Semarang

\section{Internet:}

[1] Aina Rumiati Aziz, 2002, Perempuan Korban di Ranah Domestik, www.indoesia.com

\section{Interview:}

[1] Interview with AKBP Fahmi Afrianto, SH, SIK, MH, M.Si., April 8, 2020.

[2] Interview with the Head of PPA Mrs. Umarsini on April 9, 2020. 